\title{
Cavitated charcoal - an innovative method for improving the biochemical properties of soil
}

\author{
Krzysztof Gondek $^{1}$, Monika Mierzwa-Hersztek ${ }^{1}$, Wojciech Grzymała ${ }^{2}$, and Tomasz Głąb ${ }^{1}$ \\ ${ }^{1}$ Uniwersytet Rolniczy im. Hugona Kollataja w Krakowie \\ ${ }^{2}$ BirkoProject
}

July 22, 2020

\begin{abstract}
The study was carried out with cavitated charcoal that were introduced into loamy sand and clay at rates of $1.76 \%, 3.5 \%, 7.0 \%$, and $14.0 \%$. The highest introduction rate of the material (14.0\%) increased the content of total carbon (CTot) by $197 \%$ in the loamy sand and by $19 \%$ in the clay compared to that in the control treatments. The application of cavitated charcoal did not significantly change the total content of heavy metals. Regardless of the element and the soil used, the application of cavitated charcoal reduced the content of the CaCl2-extracted forms of heavy metals. Following the application of cavitated charcoal, the loamy sand soil presented an even lower content of the most mobile forms of the studied elements. It should also be noted that regardless of the soil texture, mobile forms of the elements decreased with the increased cavitated charcoal rate. The respiratory activity values of the soils into which cavitated charcoal was introduced were low, which indicates a large number of dormant microorganisms. Additionally, the results of dehydrogenase and urease activity indicated the low metabolic activity of the microbial population in the soils, especially with the relatively high rates $(7.0 \%$ and $14.0 \%)$ of cavitated charcoal. However, the cavitated charcoal used in the study showed a significant, positive effect on the amount of biomass Sorghum saccharatum (L.), and its application significantly reduced the heavy metal content in the biomass of Sorghum saccharatum (
\end{abstract}

\begin{abstract}
Thermal biomass transformation products are considered to be one of the best materials for improving soil properties. The use of cavitated charcoal is not described in the literature. The study was carried out with $10 \%$ aqueous charcoal mixture that were introduced into loamy sand and clay at rates of $1.76 \%, 3.5 \%$, $7.0 \%$, and $14.0 \%$. The application of cavitated charcoal reduced the acidification of both soils. The highest introduction rate of the material (14.0\%) increased the content of total carbon $\left(\mathrm{C}_{\mathrm{Tot}}\right)$ by $197 \%$ in the loamy sand and by $19 \%$ in the clay compared to that in the control treatments. The application of cavitated charcoal did not significantly change the total content of heavy metals. The effect of the application of cavitated charcoal on the bioavailability of heavy metals was tested after extracting the most mobile forms of $\mathrm{Cu}, \mathrm{Cd}, \mathrm{Pb}$, and $\mathrm{Zn}$ with a $0.01 \mathrm{~mol} \mathrm{dm^{-3 }}$ solution of $\mathrm{CaCl}_{2}$. Regardless of the element and the soil used, the application of cavitated charcoal reduced the content of the $\mathrm{CaCl}_{2}$-extracted forms of heavy metals. Following the application of cavitated charcoal, the loamy sand soil presented an even lower content of the most mobile forms of the studied elements. It should also be noted that regardless of the soil texture, mobile forms of the elements decreased with the increased cavitated charcoal rate. The respiratory activity values of the soils into which cavitated charcoal was introduced were low, which indicates a large number of dormant microorganisms. Additionally, the results of dehydrogenase and urease activity indicated the low metabolic activity of the microbial population in the soils, especially with the relatively high rates $(7.0 \%$ and $14.0 \%)$ of cavitated charcoal. However, the cavitated charcoal used in the study showed a significant, positive effect on the amount of biomass Sorghum saccharatum (L.), and its application significantly reduced the heavy metal content in the biomass of Sorghum saccharatum (L.).
\end{abstract}


Keywords: cavitation, charcoal, soil, enzymatic activity, plant, heavy metals

\section{Introduction}

The appropriate use of waste biomass is one of the ways to achieve sustainable agriculture in the $21^{\text {st }}$ century. This approach will help create a product capable of improving soil characteristics in terms of its chemical and biological properties, as well as the quantity and chemistry of obtained plant biomass (Glaser, 2007). Significant amounts of waste biomass are generated in the world, and the instability of this waste makes its transformation often a key problem for the environment. The product of thermal biomass transformation is charcoal with properties similar to biochar. Solid products of thermal biomass transformation, due to their multiple specific properties, are often referred to as environmentally friendly materials (Deenik et al., 2010; Oliveira et al., 2017). The beneficial effects of these materials on soil water retention capacity, cation exchange capacity, and improvement of soil function as a carbon reservoir is noted here because of the high C content in these environmentally friendly materials and their resistance to microbial degradation (Cheng et al., 2008; Tan et al., 2017). Despite many studies on the effect of charcoal and biochar on the environment, it was not possible to clearly define the mechanisms of their action (Dieguez-Alonso et al., 2018). The increased number of tests carried out have proven that the effect of thermally transformed organic materials on soil and plant properties is varied. Their effect is also conditioned by, among others, the type of feedstock, production conditions, material rate, location of tests and type of plant cultivated (Deenik et al., 2010; O'Connor et al., 2018). Deenik et al. (2010) demonstrated that the independent application of thermally transformed organic materials worsened the conditions for plant growth and development, probably due to limited nitrogen access and stimulation of soil microorganismal growth. The study of Kloss et al. (2013) indicated a similar plant response, especially in the first two years after the application of biochar. In addition, these authors noted a decrease in the content of some trace elements in plant biomass. According to Kloss et al. (2013), even with additional mineral fertilisation, the use of thermally transformed organic materials creates the risk of a short-term reduction in plant growth and development.

Previous studies on charcoal and biochar were focused not only on determining the structure and chemistry of these materials but also on searching for new solutions aimed at enriching them with various components and modifying their production process (Jassal et al., 2015; Gondek et al., 2018). Given the properties of charcoal and the way it is applied, as well as the resulting environmental problems, there is a need to identify alternative production methods (form) or preparations for use (Montanarella and Lugato, 2013). Due to the nature of the cavitation process, it is possible to homogenise cavitated material with the implosion of gas bubbles. In the case of hydrodynamic and acoustic cavitation, cavitation bubbles are present in liquid as a result of local ruptures of the continuous medium caused by high tensile forces. These forces arise from local sudden pressure decreases that may occur either in hydrodynamic processes or in a high-intensity ultrasonic field $(20 \mathrm{kHz}-1 \mathrm{MHz})$ (Lenik and Ozonek, 2012). The cavitation process can be modified by adding various types of chemical substances or by changing the physical parameters of the process (Nakashima et al., 2016).

The aim of the study was to assess the effect of charcoal after cavitation on the chemical and biochemical properties of soil, as well as on the quantity and chemistry of Sorghum saccharatum (L.) biomass.

\section{Materials and methods}

\subsection{Cavitation of charcoal}

The study was carried out on charcoal obtained from an industrial installation located in the Bieszczady Mountains (southeastern Poland). The production process was performed using deciduous wood. Before starting dry distillation, feedstock was ground and treated with drying gases at $160-180{ }^{\circ} \mathrm{C}$. Then, the material was placed in a retort. After closing the retort, the residual water evaporates, and the thermal decomposition of the wood begins. It is initiated by hot gases of $250-300{ }^{\circ} \mathrm{C}$, moving from the central part of the retort (annealing zone). The process is exothermic. The organic mass of wood is charred. The partially charred wood mass has a reduced volume; hence, it moves down the retort and enters the annealing zone. Here, at $500-550{ }^{\circ} \mathrm{C}$, the final form of charcoal is formed (Lewandowski and Milchert, 2011). 
The cavitation process was carried out in $10 \% \mathrm{w} / \mathrm{w}$ aqueous charcoal mixture (particle size of 0-0.5 mm). The suspension was placed in a tank to which a $2.5 \mathrm{~kW}$ cavitation pump was connected. After passing through the pump, the suspension was returned to the tank (closed circuit). The micronisation time for $150 \mathrm{dm}^{3}$ of the suspension was 2 hours, and the temperature increase during the cavitation process was from $40{ }^{\circ} \mathrm{C}$ (initial stage) to $60{ }^{\circ} \mathrm{C}$ (final stage).

\subsection{Chemical composition of charcoal after cavitation}

To characterize the properties of the charcoal suspension after cavitation (CHAR-C), the following properties were determined in the material: electrical conductivity - conductometrically, $\mathrm{pH}$ - potentiometrically, and the content of $\mathrm{N}_{-} \mathrm{NH}_{4}$ and $\mathrm{N}-\mathrm{NO}_{3}$ - using ion selective electrodes. The contents of macroelements (P, K, $\mathrm{Ca}$, and $\mathrm{Mg}$ ) and trace elements $(\mathrm{Cu}, \mathrm{Fe}, \mathrm{Mn}$, and $\mathrm{Zn})$ were determined after mineralising the sample in a mixture of concentrated $\mathrm{HNO}_{3}$ and $\mathrm{HClO}_{4}$ (3:2). The contents of the studied elements were determined in the obtained solutions by inductively coupled plasma optical emission spectrometry (ICP-OES, Perkin Elmer Optima 7300 DV, Waltham, USA) (Oleszczuk et al. 2007). The material chemical composition is presented in Table 1.

\subsection{Growth experiment}

The experiment was carried out on two soil types: loamy sand (LS) and clay (C) collected from the 0-0.2 m layer in southern Poland. The properties of the soils used in the experiment are presented in Table 2.

The growth experiment was conducted in containers with a capacity of $500 \mathrm{~g}$ of soil dry mass. The experimental scheme was the same for LS and C soils and included the following treatments: the control with no cavitated charcoal (LS-0; C-0), a treatment with a $1.76 \%$ addition of cavitated charcoal (LS-1; C-1), a treatment with a $3.5 \%$ addition of cavitated charcoal (LS-2; C-2), a treatment with a $7.0 \%$ addition of cavitated charcoal (LS-3; C-3), and a treatment with a $14.0 \%$ addition of cavitated charcoal (LS-4; C-4). After introducing cavitated charcoal, distilled water (up to $45 \%$ water capacity) was added to the soils and thoroughly mixed with the material. Subsequently, soils with and without the addition of charcoal were placed in PVC containers. After 24 hours, seeds of Sorghum saccharatum SOS 101116 were sown. During plant growth, the soil moisture content was maintained at $60 \%$ of the water capacity. The experiment was carried out under laboratory conditions at $25 \pm 3{ }^{\circ} \mathrm{C}$ for 156 days. Then, plant aboveground biomass was collected, and plant roots were separated from the soil block and thoroughly washed with distilled water. The collected biomass was dried to a constant weight at $105{ }^{\circ} \mathrm{C}$, and then, the amount of biomass was determined. To determine the chemical composition, the plant material was ashed in a chamber furnace at $450{ }^{\circ} \mathrm{C}$ for 12 hours, and the residue was dissolved in diluted $(1: 2)(\mathrm{v} / \mathrm{v})$ nitric acid. The contents of the studied trace elements were determined by inductively coupled plasma optical emission spectrometry (ICP-OES, Perkin Elmer Optima 7300 DV, Waltham, USA) (Oleszczuk et al., 2007).

\subsection{Biochemical properties of soil}

The soil biological activity measurements included enzymatic activity and soil respiration. Dehydrogenase activity (DhA) was determined by the method in Thalmann (1968) using triphenyltetrazolium chloride (TTC) as the electron acceptor. Samples were incubated at $37 \pm 2{ }^{\circ} \mathrm{C}$ for 24 hours. The enzymatic activity of the dehydrogenases was determined by colourimetry using a Backman DU 640 spectrophotometer (Beckman Coulter, Woonsocket, USA) at a wavelength of $546 \mathrm{~nm}$.

Urease activity (Ure) was determined by the Zantua and Bremner (1975) method, with urea as a substrate, after a 18 hour incubation at $37^{\circ} \mathrm{C}$. The enzymatic activity of ureases was determined by colourimetry using a Backman DU 640 spectrophotometer at a wavelength of $470 \mathrm{~nm}$.

Basal respiration (BR) was determined according to the ISO 16072 (International Organization for Standardization, 2002) method. Moist soil subsamples $(20 \mathrm{~g})$ were incubated at $20 \pm 2{ }^{\circ} \mathrm{C}$ for 24 hours. The released $\mathrm{CO}_{2}$ was absorbed in a solution of $0.05 \mathrm{M} \mathrm{NaOH}$ and precipitated as barium carbonate with the addition of a $0.5 \mathrm{M} \mathrm{BaCl}_{2}$ solution. The unconsumed sodium hydroxide was titrated with $0.1 \mathrm{M} \mathrm{HCl}$ in the presence 
of phenolphthalein as an indicator, and the amount of $\mathrm{CO}_{2}$ was calculated (ISO 16072: 2002). Substrateinducted respiration (SIR) was determined by the quantification of carbon dioxide evolution shortly (6 hours) after glucose addition (aqueous solution equivalent to $10 \mathrm{~g}$ glucose per $\mathrm{kg}$ of soil) (ISO 14240-1: 1997). The respiratory-activation quotient $(\mathrm{QR})$ was calculated by dividing the $\mathrm{BR}$ rate by the SIR rate according to ISO 17155 (2012).

\subsection{Chemical properties of soil}

In $1 \mathrm{~mm}$ of dried, sieved soil samples, the following parameters were determined: $\mathrm{pH}$ - potentiometrically, in the suspension of soil and water as well as soil and $1 \mathrm{~mol}[?] \mathrm{dm}^{-3}$ solution of $\mathrm{KCl}$ (soil:solution $=1: 2.5$ ) and electrical conductivity (EC) - conductometrically. The total carbon $\left(\mathrm{C}_{\mathrm{Tot}}\right)$ and total nitrogen $\left(\mathrm{N}_{\mathrm{Tot}}\right)$ contents were determined with a CNS analyser Vario MAX Cube (Elementar, Langenselbold, Germany) (Elementar Analysensysteme, 2013). Bioavailable trace elements were extracted from the soil for 2 hours with a 0.01 mol dm${ }^{-3}$ solution of $\mathrm{CaCl}_{2}$ (soil:solution $=1: 10$ ) (Houba et al., 2000). In the obtained extracts, the studied elements were determined by inductively coupled plasma optical emission spectrometry (ICP-OES, Perkin Elmer Optima 7300 DV, Waltham, USA) (Oleszczuk et al., 2007).

\subsection{Statistical analysis}

The experiment was carried out in three replicates. An analysis of variance for a randomized design was performed using the statistical software package Statistica v. 13.3 (StatSoft Inc., Tulsa, OK, USA) (Table S1 in Supplementary Materials). The distribution of the data was checked for normality using the Shapiro-Wilk test. The homogeneity of variance was checked using Levene's test. The multiple means comparison was conducted using a Duncan test with a $\mathrm{P}<0.05$ level of significance. Pearson's correlation analysis was used to analyse the correlation between the CHAR-C rate and biochemical parameters and biomass productivity (Table S2). For data where significant values of correlation coefficients $(r)$ were observed, the results of the linear regression models are presented in graphical form, together with regression equations and coefficients of determination $\left(R^{2}\right)$.

\section{Results and discussion}

\subsection{Properties of cavitated charcoal and soils}

The cavitated charcoal (CHAR-C) used in the study had an alkaline $\mathrm{pH}$ and high electrical conductivity (EC). The content of macronutrients, e.g., calcium and potassium, varied in the studied material (Table 1). The content of heavy metals was lower than that observed in biochar produced from plant biomass (Gondek et al., 2017). The LS and C soils used in the study had different granulometric compositions and chemical properties (Table 2). Both soils were characterised by the natural content of heavy metals examined in this study.

\subsection{Effect of the addition of cavitated charcoal on selected chemical properties of soils}

The application of CHAR-C reduced the acidification of the LS and C soil (Table 3). Due to the greater buffering of the $\mathrm{C}$ soil than of the LS soil, the efficiency of the deacidification effect of CHAR-C was lower. According to the literature, the application of charcoal in soil reduces soil acidification as a result of active compounds and alkaline elements accumulated in this material. The durability of the charcoal deacidifying effect depends on soil and climatic conditions and, as indicated by the published data, on the rate of alkaline cation leaching to the deeper layers of the soil profile (Hardy et al., 2016; Mastrolonardo et al., 2019).

An increase in the electrical conductivity (EC) value was noted in proportion to the amount of CHAR-C introduced into the LS soil; however, the parameter increase was significant only in the LS-4 treatment with the highest CHAR-C rate (Table 3). Introduction of the $7.0 \%(\mathrm{C}-3)$ and $14.0 \%(\mathrm{C}-4)$ rates of CHAR-C into the $\mathrm{C}$ soil significantly increased the EC values by $80 \%$ and $109 \%$, respectively, compared to in the control soil (C-0). Due to the lack of data in the literature on the effect of cavitated charcoal on soil EC values, the obtained results were referenced in terms of the effect of applied biochar to the soil on the parameter value. The literature provides examples of increases in EC values after the application of biochar. The EC increase 
was generally proportional to the rate of the material used. This phenomenon results from the release of salts from organic connections that easily pass into the soil solution, increasing the pool of ionic forms that actively conduct an electrical charge (Gondek and Mierzwa-Hersztek, 2016).

Significant differences in the total carbon $\left(\mathrm{C}_{\text {Tot }}\right)$ content in the soils were found after using the same rates of CHAR-C (Table 3). Considering only the smallest rate of CHAR-C introduced into the LS soil, an over $40 \%$ increase in the $\mathrm{C}_{\text {Tot }}$ content was noted, while this content in the $\mathrm{C}$ soil decreased by over $8 \%$ compared to that in the control. The highest rate of CHAR-C resulted in a $197 \%$ increase in the $\mathrm{C}_{\text {Tot }}$ content in LS and a $19 \%$ increase in $\mathrm{C}$ compared to that in the control treatments. The trend in the increased $\mathrm{C}_{\text {Tot }}$ in this study is confirmed by the literature on the charcoal effect on the carbon content in soil (Hardy and Dufey, 2017; Mastrolonardo et al., 2019). However, it should be noted that there are large discrepancies in the values of the increased $\mathrm{C}_{\text {Tot }}$ content in soils, which are probably dictated by the type of charcoal used, its rate, and climatic conditions (Kerre et al., 2016).

The total nitrogen content differed significantly but only between soils (Table 3). No significant changes in the total nitrogen $\left(\mathrm{N}_{\mathrm{Tot}}\right)$ content were noted after the application of CHAR-C. The literature lacks information on the effect of the tested product on the $\mathrm{N}$ content in soil. Hardy et al. (2016) did not report significant differences in the nitrogen content between the soil fertilised with charcoal and the control soil. Hirsch et al. (2017) discovered even lower N content in soils into which charcoal was introduced. However, it should be noted that charcoal contains a nitrogen pool in a heterocyclic form that is practically inaccessible to plants, creating the need to include fertilisation with mineral forms of this element.

\subsection{Effect of the addition of cavitated charcoal on the content of selected heavy metals in soils}

Regardless of the soil (LS or C), the applied CHAR-C rates did not significantly change the total contents of the studied heavy metals (Table 4). Significant differences in the studied element contents were dictated by the type of soil used.

The effect of the application of CHAR-C on the bioavailability of heavy metals was tested after extracting the most mobile forms of $\mathrm{Cu}, \mathrm{Cd}, \mathrm{Pb}$, and $\mathrm{Zn}$ with a $0.01 \mathrm{~mol}[?] \mathrm{dm}^{-3}$ solution of $\mathrm{CaCl}_{2}$ (Table 4). Regardless of the element and soil used, the application of CHAR-C reduced the content of $\mathrm{CaCl}_{2}$-extracted forms of heavy metals. Following the application of CHAR-C, the LS soil presented a relatively low content of the most mobile forms of the studied elements. It should also be noted that, regardless of the soil, mobile forms decreased with an increased CHAR-C rate.

Recent studies indicate that thermally transformed organic materials, including charcoal and biochar, exhibit sorption capacity for heavy metal ions (Miura and Shiratani, 2018; Mierzwa-Hersztek et al., 2019). These materials have a large specific surface area, i.e., a surface on which there are functional groups that are active in the sorbing of heavy metal ions. The sorption capacity of charcoal and biochar is determined, among others, by the concentration of heavy metals in the soil solution. In unpolluted soils, the natural consequence of using these materials is the reduction in the content of the most available element forms (Miura and Shiratani, 2018; Mierzwa-Hersztek et al., 2019). In our study, the increase in soil pH after the use of CHAR-C was one of the important factors reducing the content of the most available heavy metals (Gondek and Mierzwa-Hersztek, 2016).

\subsection{Effect of the addition of cavitated charcoal on the value of selected biochemical parameters of soils}

The respiratory activity of microorganisms in soil depends on their physiological state and environmental conditions. Despite the large variability in the soil parameters, such as humidity, $\mathrm{pH}$, temperature, availability of nutrients, and structure, it is believed that soil respiratory activity is a very sensitive parameter closely related to other soil biological properties (Han et al., 2007; Mierzwa-Hersztek et al., 2018). Values of basal respiration (BR) determined in our study differed significantly between the soils. The largest significant increase in the BR value compared to that in the control was found in treatments with $7.0 \%$ (LS-3 and C-3) and $14.0 \%$ (LS-4 and C-4) CHAR-C (Table 5). Compared to the control treatments, in LS-3 and LS-4, the BR increase was $38 \%$ and 58\%, respectively, and in C-3 and C-4, it was $20 \%$ and 19\%, respectively. Linear 
regression for the relationship between BR and the CHAR-C rate is presented in Figure 4.

The addition of glucose to the analysed soil samples significantly increased the respiration rate due to the presence of a source of easily available carbon in the microorganism habitat. Additionally, it can be concluded that there were no inhibitory substances in these soils or they were in concentrations that did not inhibit the viability of dormant microorganisms. Similar to BR, the largest increase in the SIR parameter was determined in soils with the highest CHAR-C rates. In both soils, the smallest rate of CHAR-C (LS-1, C-1) reduced the SIR value (Table 5).

The respiratory activity coefficient quotient (QR) determined in the study, which illustrates the number of dormant or active microorganisms, ranged from 0.11 to 0.14 for the LS soil and from 0.11 to 0.22 for the C soil (Table 5). As reported by Eisentraeger et al. (2000), a respiratory activity coefficient ranging from 0.1 to 0.3 is low and indicates a large amount of dormant microorganismal biomass as well as a low rate of bioremediation with potential toxic substances in the soil. From this point of view, a high BR value is most desirable for soil. Considering the observations of the cited authors, the poorest microbiological parameters were found in soils without CHAR-C (LS-0, C-0) and with $8.8 \mathrm{ml}$ (LS-1, C-1) and $17.5 \mathrm{ml}$ (LS -2, C-2) of CHAR-C.

Biological processes affecting soil fertility and productivity are mainly associated with soil microbial activity, which translates into the number of enzymes produced (Beheshti et al., 2018). Table 5 presents the activity of dehydrogenases (DhA) associated with the transformation of carbon compounds and ureases (Ure) involved in the transformation of nitrogen compounds. The highest DhA and Ure activity occurred in the control treatments. Regardless of the soil and rate, the application of CHAR-C reduced the DhA activity (Figure 4). Compared to the control, the treatment with the highest rate of CHAR-C (70 ml) reduced the DhA activity by $57 \%$ in the LS soil and by $24 \%$ in the C soil.

The lowest CHAR-C rates (1.76\% and 3.5\%) significantly increased the Ure activity in all soils. The application of $7.0 \%$ and $14.0 \%$ rates drastically reduced the Ure activity in the LS soil, making the parameter value equal to that determined in control soil. The Ure activity in the $\mathrm{C}$ soil was also reduced under the influence of the same CHAR-C rates, but the decrease was not as rapid.

Enzymatic activity is a very sensitive indicator of changes in soil after applying various materials. The literature presents both positive and negative effects of introducing thermally transformed organic materials into the soil (Tian et al., 2016; Vithange et al., 2018; Lammirato et al., 2011; Ameloot et al., 2013). The varied activity of individual enzymes can occur for many reasons. The most commonly indicated reasons in the literature are the content of $\mathrm{C}$ and $\mathrm{N}$ and the relationship between these components. Equally important is the available content of both elements (Paz-Ferreiro et al., 2012). One should also remember that the introduced rate of material is of key importance in maintaining optimal enzymatic activity in the soil. Our studies clearly showed that higher CHAR-C rates had adverse effects on both DhA and Ure activities. The cause could have been, inter alia, increased EC values and limited availability of other nutrients. The study results published by Mierzwa-Hersztek et al. (2019) indicated that the interaction of many factors significantly affects the enzymatic activity and microbiocenotic composition of soil.

3.5. Effect of the addition of cavitated charcoal on the amount and content of selected heavy metals in Sorghum saccharatum (L.) biomass

Significantly higher amounts of Sorghum saccharatum (L.) aboveground biomass compared to that in the control occurred in the LS soil after applying 3.5\% (LS-2), 7.0\% (LS-3), and $14.0 \%$ (LS-4) rates of cavitated charcoal (Figure 1). For the C soil, the significant increase in the amount of Sorghum saccharatum (L.) aboveground biomass occurred with the $7.0 \%(\mathrm{C}-3)$ and $14.0 \%(\mathrm{C}-4)$ rates. The largest amounts of biomass collected in the LS-4 and C- 4 treatments were $25 \%$ and $145 \%$ higher, respectively, compared to that collected in the control treatments (LS-0 and C-0). The relationship between the aboveground biomass and CHAR-C rate is presented in Figure 2.

The study revealed different trends in the amount of Sorghum saccharatum (L.) root biomass in the LS and 
C soils. For all CHAR-C rates, the amount of Sorghum saccharatum (L.) root biomass was higher in the LS soil than in the control (Figure 3). On the other hand, when compared to that in the control soil, the root biomass in the $\mathrm{C}$ soil was lower after applying two lower rates (treatments $\mathrm{C}-1$ and $\mathrm{C}-2$ ) and higher after applying two higher rates (treatments C-3 and C-4).

There are numerous accounts in the literature on the significant fertilisation potential of thermally converted organic materials (charcoal, biochar). Some studies also indicate the sorption capacity of these materials in relation to nutrients. According to Yao et al. (2012), thermally converted organic materials can effectively sorb nitrate nitrogen, ammonium nitrogen or phosphates; however, the properties of such materials, including $\mathrm{pH}$, surface acid groups, and ion exchange capacity, can have a great impact on the ability to adsorb nutrients (Yao et al. 2012, Morales et al. 2013, Mierzwa-Hersztek et al. 2019). Our results indicate that in addition to improving soil properties, there is also a risk of limiting the availability of nutrients after applying charcoal or biochar to the soil. In practise, it seems reasonable to combine charcoal or biochar applications with mineral fertilisers that meet the nutritional needs of plants, at least in the initial periods of their growth (Deenik et al. 2010). Although there are only a few field studies on using biochar as a slow-release fertiliser, many laboratory studies describe the application of biochar in the context of nutrient availability. It is necessary to better understand not only sorption but also desorption of nutrients because these are processes that, together with mineralisation of nutrients, control their concentration in soil solution. Consideration should be given to factors affecting the desorption of nutrients, such as soil types, feedstocks, conditions for thermal conversion, and organic material rates.

The contents of the tested heavy metals in the aboveground biomass and roots of Sorghum saccharatum (L.) differed mainly due to the soil type used (Table 6). The analysis of the contents of $\mathrm{Cd}, \mathrm{Pb}, \mathrm{Zn}$, and $\mathrm{Cu}$ in the aboveground biomass and roots of Sorghum saccharatum (L.) revealed that the heavy metal content was lower with a higher CHAR-C rate in all soils (Figure 4). This trend was clearer for the aerial parts. However, it should be noted that the significantly higher contents of $\mathrm{Cd}, \mathrm{Zn}$, and $\mathrm{Cu}$ in Sorghum saccharatum (L.) biomass in the $\mathrm{C}$ soil than in the other soils resulted from the greater acidification of that soil. The determined values of the tested heavy metals in Sorghum saccharatum (L.) reflected changes in their availability in the soil.

\section{Conclusions}

Cavitated charcoal has great potential to deacidify soils and increase the $\mathrm{C}$ content. The application of cavitated charcoal does not increase the total content of heavy metals; however, it substantially reduces their mobility. The determined values of the base respiratory activity of the soils into which CHAR-C was introduced were low, which indicates a large number of dormant microorganisms, as confirmed by the values of induced respiratory activity. The obtained results of DhA and Ure activity showed the low metabolic activity of the microbial population in the soils, especially at high rates $(7.0 \%$ and $14.0 \%)$ of CHAR-C. The cavitated charcoal dust used in the study showed high-yielding properties, and its application significantly reduced the heavy metal content in the biomass of Sorghum saccharatum (L.).

\section{Acknowledgements}

The research was financed by the Ministry of Science and Higher Education of the Republic of Poland.

Conflict of interest: The authors declare that they have no conflicts of interest.

Data Availability Statement: Data available on request from the authors

\section{References}

Ameloot, N., Neve, S.D., Jegajeevagan, K., Yildiz, G., Buchan, D., Funkuin, Y.N., Prins W., Bouckaert, L., Sleutel, S. 2013. Short-term $\mathrm{CO}_{2}$ and $\mathrm{N}_{2} \mathrm{O}$ emissions and microbial properties of biochar amended sandy loam soils. Soil Biol. Biochem., 57, 401-410.

Beheshti, M., Etesami, H., Alikhani, H.A. 2018. Effect of different biochars amendment on soil biological indicators in a calcareous soil. Environ. Sci. Pollut. Res., 25 (15), 1-10. 
Cheng, C.H., Lehmann, J., Thies, J.E., Burton, S.D. 2008. Stability of black carbon in soils across a climatic gradient. J. Geophys. Res. Biogeosci., 113, 1-10.

Deenik, J., McClellan, T., Uchera, G., Antal, M.J., Campbell, S. 2010. Charcoal volatile matter content influences plant growth and soil nitrogen transformations. Soil Sci. Soc. Amer. J., 74 (4), 1259-1270.

Dieguez-Alonso, A., Funke, A., Anca-Couce, A., Rombola, A.G., Ojeda, G., Bachmann, J., Behrendt, F. 2018. Towards biochar and hydrochar engineering-influence of process conditions on surface physical and chemical properties, thermal stability, nutrient availability, toxicity and wettability. Energies, 11 (3), 496.

Eisentraeger, A., Maxam, G., Rila, J.P., Dott, W. 2000. A stepwise procedure for assessment of the microbial respiratory activity of soil samples contaminated with organic compounds. Ecotoxicol. Environ. Saf., 47, 65-73.

Elementar Analysensysteme GmbH, 2013. Operating instructions vario MAX cube pp. 407.

Glaser, B., 2007. Prehistorically modified soils of central Amazonia: a model for sustainable agriculture in the twenty-first century. Philos. Trans. R. Soc. B. Biol. Sci., 362 (1478), 187-196.

Gondek, K., Mierzwa-Hersztek, M. 2016. Effect of low-temperature biochar derived from pig manure and poultry litter on mobile and organic matter-bound forms of $\mathrm{Cu}, \mathrm{Cd}, \mathrm{Pb}$ and $\mathrm{Zn}$ in sandy soil. Soil Use Manage., 32, 357-367.

Gondek, K., Mierzwa-Hersztek, M., Baran, A., Szostek, M., Pieniążek, R., Pieniążek, M., Stanek-Tarkowska, J., Noga, T. 2017. The effect of low-temeperature conversion of plant materials on chemical composition and ecotoxicity of biochars. Waste Biom. Valor., 8, 599-609.

Gondek, K., Mierzwa-Hersztek, M., Kopeć M., Mróz, T. 2018. The influence of biochar with magnesium and sulfur on the amount of Perennial ryegrass biomass and selected chemical properties and biological of sandy soil. Comm. Soil Sci. Plant Anal., 49, 11, 1257-1265.

Han, G., Zhou, G., Xu, Z., Yang, Y., Liu, J., Shi K. 2007. Soil temperature and biotic factors drive the seasonal variation of soil respiration in a maize (Zea mays L.) agricultural ecosystem. Plant Soil, 291, 15-26.

Hardy, B., Cornelis, J.T., Houben, D., Lambert, R., Dufey, J.E. 2016. The effect of pre-industrial charcoal kilns on chemical properties of forest soil of Wallonia, Belgium. Eur. J. Soil Sci., 67, 206-216.

Hardy, B., Dufey, J.E. 2017. The resistance of centennial soil charcoal to the "Walkley-Black" oxidation. Geoderma, 303, 37-43.

Hirsch, F., Raab, T., Ouimet, W., Dethier, D., Schneider, A., Raab, A. 2017. Soils on historic charcoal hearths: terminology and chemical properties. Soil Sci. Soc. Am. J., 81, 1427-1435.

Houba, V.J.G., Temminghoff, E.J.M., Gaikhorst, G.A., van Vark, W. 2000. Soil analysis procedures using $0.01 \mathrm{M}$ calcium chloride as extractation reagent. Comm. Soil Sci. Plant Anal., 31 (9-10), 1299-1396.

ISO 16072:2002. Soil quality - Laboratory methods for determination of microbial soil respiration.

ISO 17155:2012. Soil quality - Determination of abundance and activity of soil microflora using respiration curves.

ISO PN-EN ISO 14240-1:2011. Soil quality - Determination of soil microbial biomass - Part 1. Soil Quality - Determination Of Soil Microbial Biomass - Part 1: Substrate-Induced Respiration Method (ISO 142401:1997).

Jassal, R.S., Johanson, M.S., Molodovskaya, M., Black, A., Jollymore, A., Sveinson, K. 2015. Nitrogen enrichment potential of biochar in relation to pyrolysis temperature and feedstock quality. J. Environ. Manage., $152,140-144$. 
Kerré, B., Bravo, C.T., Leifeld, J., Cornelissen, G., Smolders, E. 2016. Historical soil amendment with charcoal increases sequestration of non-charcoal carbon: a comparison among methods of black carbon quantification. Eur. J. Soil Sci., 67, 324-331.

Kloss, S., Zehetner, F., Wimmer, B., Buecker, J., Rempt, F., Soja, G. 2014. Effects on soil fertility and cropgrowth under greenhouse conditions. J. Plant Nutr. Soil Sci., 177, 3-15.

Lammirato, C., Miltner, A., Kaestner M. 2011. Effects of wood char and activated carbon on the hydrolysis of cellobiose by b-glucosidase from Aspergillus niger. Soil Biol. Biochem., 43, 1936-1942.

Lenik, K., Ozonek, J. 2012. The evaluation of the cavitation number in hydrodynamic cavitation including the influence of the orifice plate geometry. Automat. Robot. Measur., 6, 60-63.

Lewandowski, G., Milchert, E. 2011. Modern installation of dry distillation of wood. Chemist, 65 (12), 13011306.

Mastrolonardo, G., Calderaro, Ch., Cocozza, C., Hardy, B., Dufey, J., Cornelis, J.T. 2019. Long-term effet of charcoal accumulation in hearth soil on tree growth and nutrient cycling. Front. Environ. Sci., 7 (51), 1-15.

Mierzwa-Herstek, M., Gondek, K., Bajda, T., Kopeć, M. 2019. Use of biochar and a zeolite as adsorbents of mineral pollutions. Chem. Indust., 98(12), 1969-1972.

Mierzwa-Hersztek, M., Gondek, K., Klimkowicz-Pawlas, A., Chmiel, M., Dziedzic, T., Taras, H. 2019. Assessment of soil quality after biochar application based on enzymatic activity and microbial composition. Int. Agroph., 33(3), 331-336.

Mierzwa-Hersztek, M., Klimkowicz-Pawlas, A., Gondek, K. 2018. Influence of Poultry Litter and Poultry Litter Biochar on Soil Microbial Respiration and Nitrifying Bacteria Activity. Waste Biom. Valor., 9, 379-389.

Miura, A., Shiratani, E. 2018. practical use of charcoal as a remedioation material for cadmium-polluted soil. Environ. Ecol. Res., 6(2), 130-136.

Montanarella, L., Lugato, E. 2013. The application of biochar in the EU: Challenges and opportunities. Agronomy, 3, 462-473.

Morales, M., Comerford, N., Guerrini, I., Falcão, N., Reeves, J. 2013. Sorption and desorption of phosphate on biochar and biochar-soil mixtures. Soil Use Manage., 29, 306-314.

Nakashima, K., Ebi, Y., Shibasaki-Kitakawa, N., Soyama, H., Yonemoto, T. 2016. Hydrodynamic cavitation reactor for efficient pretreatment of lignocellulosic biomass. Indust. Eng. Chemi. Res., 55(7), 1866-1871.

O'Connor, D., Peng, T., Zhang, J., Tsang, D.C.W., Alessi, D.S., Shen, Z., Bolan, N.S., Hou, D. 2018. Biochar application for the remediation of heavy metal polluted land: a review of in situ field trials. Sci. Tot. Environ., 619-620, 845-826.

Oleszczuk, N., Castro, J.T., da Silva, M.M., Korn, Md., Welz, B., Vale, M.G. 2007. Method development for the determination of manganese, cobalt and copper in green coffee comparing direct solid sampling electrothermal atomic absorption spectrometry and inductively coupled plasma optical emission spectrometry. Talanta, 73(5), 862-869.

Oliveira, F.R., Patel, A.K., Deb, P.J., Adhikari, S., Lu H., Khanal, S.K. 2017. Environmental application of biochar: Current status and perspectives. Biores. Technol., 246, 110-122.

Paz-Ferreiro, J., Gascó, G., Gutierrez, B., Mendez, A. 2012. Soil biochemical activities and geometric mean of enzyme activities after application of sewage sludge and sewage sludge biochar to soil. Bil. Fertil. Soils, $48,511-517$.

Tan, Z., Lin, C.S.K., Ji, X., Rainey, T.J. 2017. Returning biochar to fields: a review. Appl. Soil Ecol., 116, $1-11$. 
Thalmann, A. 1968. Methods of dehydrogenase activity determination with triphenyltetrazoliumchlorid (TTC) (in German). Landwirtsch. Forsch, 21, 249-258.

Tian, J., Wang, J., Dippold, M., Gao, Y., Blagodatskaya, E., Kuzyakov, Y. 2016. Biochar affects soil organic matter cycling and microbial functions but does not alter microbial community structure in a paddy soil. Sci. Total Environ., 556, 89-99.

Vithanage, M., Bandara, T., Al-Wabel, M.I., Abduljabbar, A., Usman, A.R.A., Ahmad, M., Ok, Y.S. 2018. Soil enzyme activities in waste biochar amended multi-metal contaminated soil; effect of different pyrolysis temperatures and application rates. Comm. Soil Sci. Plant Anal., 49(5), 635-643.

Yao, Y., Gao, B., Zhang, M., Inyang, M., Zimmerman, A.R. 2012. Effect of biochar amendment on sorption and leaching of nitrate, ammonium, and phosphate in a sandy soil. Chemosphere 89, 1467-1471.

Zantua, M.I., Bremner J.M. 1975. Comparison of methods of assaying urease activity in soils. Soil Biol. Biochem., 7, 291-295.

\section{Hosted file}

Table 1.docx available at https://authorea.com/users/298523/articles/471529-cavitatedcharcoal-an-innovative-method-for-improving-the-biochemical-properties-of-soil

\section{Hosted file}

Table 2.docx available at https://authorea.com/users/298523/articles/471529-cavitatedcharcoal-an-innovative-method-for-improving-the-biochemical-properties-of-soil

\section{Hosted file}

Table 3.docx available at https://authorea.com/users/298523/articles/471529-cavitatedcharcoal-an-innovative-method-for-improving-the-biochemical-properties-of-soil

\section{Hosted file}

Table 4.docx available at https://authorea.com/users/298523/articles/471529-cavitatedcharcoal-an-innovative-method-for-improving-the-biochemical-properties-of-soil

\section{Hosted file}

Table 5.docx available at https://authorea.com/users/298523/articles/471529-cavitatedcharcoal-an-innovative-method-for-improving-the-biochemical-properties-of-soil

\section{Hosted file}

Table 6.docx available at https://authorea.com/users/298523/articles/471529-cavitatedcharcoal-an-innovative-method-for-improving-the-biochemical-properties-of-soil

\section{Hosted file}

Figure 1.docx available at https://authorea.com/users/298523/articles/471529-cavitatedcharcoal-an-innovative-method-for-improving-the-biochemical-properties-of-soil

\section{Hosted file}

Figure 2.docx available at https://authorea.com/users/298523/articles/471529-cavitatedcharcoal-an-innovative-method-for-improving-the-biochemical-properties-of-soil

\section{Hosted file}

Figure 3.docx available at https://authorea.com/users/298523/articles/471529-cavitatedcharcoal-an-innovative-method-for-improving-the-biochemical-properties-of-soil

\section{Hosted file}


Figure 4.docx available at https://authorea.com/users/298523/articles/471529-cavitatedcharcoal-an-innovative-method-for-improving-the-biochemical-properties-of-soil 